\title{
TEMPO NARRADO: VOZES E SILENCIAMENTOS DE TRABALHADORES RURAIS SEM TERRA RETORNADOS DO PARAGUAI
}

\section{Maria Cristina Lobregat ${ }^{1}$}

\begin{abstract}
RESUMO: Este artigo parte da interpretação das narrativas orais de trabalhadores rurais que passaram pela experiência migratória de retorno ao Brasil nas últimas três décadas. As narrativas são documentos coletados durante a pesquisa etnográfica de doutoramento realizada no Acampamento Sebastião Camargo, vinculado ao Movimento dos Trabalhadores Rurais Sem Terra. As histórias narradas por homens e mulheres, trabalhadores rurais, Sem Terra trazem as lembranças da experiência de vida nas colônias existentes no Paraguai, mas também marcam o esquecimento e, consequentemente, o silenciamento. Ao pensar estas narrativas de vida como importantes para a escrita da história da fronteira no Oeste do Paraná, destacaremos as construções de memórias coletivas e individuais dialogando com Jöel Candau e Michael Pollak, dando ênfase ao que é permitido lembrar e esquecer, processos construtivos do apagamento dos trabalhadores que passaram pela experiência de retorno. Diante disso, a reflexão será ancorada nas ideias de Abdelmalek Sayad por entender o retorno como uma condição daquele que migra.
\end{abstract}

Palavras-chave: Memória. Esquecimento. Retorno migratório.

\section{TIEMPO NARRADO: VOCES Y SILENCIOSOS DE TRABAJADORES RURALES SIN TIERRA REGRESADOS DE PARAGUAY}

RESUMEN: Este artículo parte de la interpretación de lãs narraciones orales de trabajadores rurales que pasaron por la experiencia migratoria de retorno a Brasil em las últimas tres décadas. Las narraciones son documentos recogidos durante la investigación etnográfica de doctorado realizada em El Campamento Sebastião Camargo, vinculado al Movimiento de los Trabajadores Rurales Sin Tierra. Las historias narradas por hombres y mujeres, trabajadores rurales, sin Tierra traen los recuerdos de la experiencia de vida em lãs colonias existentes em Paraguay, pero también marcanel olvido $\mathrm{y}$, consecuentemente, El silenciamiento. Al pensar estas narraciones de vida como importantes para la escritura de la historia de la frontera em el Oeste de Paraná, destacaremos lãs construcciones de memorias colectivas e individuales dialogando com Jöel Candau y Michael Pollak, aciendo énfasis a lo que se permite recordar y olvidar, procesos constructivos de la supresión de los trabajadores que pasaron por la experiencia de regreso. La reflexión será anclada em lãs ideas de Abdelmalek Sayad por entender el regreso como una condición de aquel que migra, trayendo hombres y mujeres, trabajadores rurales como protagonistas de la propia historia.

\footnotetext{
${ }^{1}$ Mestra em Letras: linguagem e identidade; Universidade Federal do Acre - UFAC; Doutoranda pelo Programa de Pós-Graduação Sociedade, Cultura e Fronteiras; Universidade Estadual do Oeste do Paraná - UNIOESTE, Foz do Iguaçu, Paraná, Brasil. Professora no Instituto Federal do Acre -IFAC. Contato: cristina.lobregat@gmail.com
}

Programas de Pós-Graduação em Ciências Sociais e Filosofia - UNIOESTE - Rua da Faculdade 645. Toledo - PR. CEP 85.903-000 Email: revistaalamedas@gmail.com 
Palabras-llaves: La memoria. Olvido. Retorno migratorio.

\section{INTRODUÇÃO}

Quando vim da minha terra Se é que vim da minha terra (não estou morto por lá) A correnteza do rio Me sussurrou vagamente Que eu havia de quedar Lá donde me despedia

Quando vim da minha terra Não vim, perdi-me no espaço, na ilusão de ter saído. Ai de mim, nunca saí. Lá estou eu, enterrado por baixo de falas mansas, por baixo de negras sombras, por baixo de lavras de ouro, por baixo de gerações, por baixo, eu sei, de mim mesmo, este vivente enganado, enganoso.

O sentimento do homem que deixa sua terra natal, a vontade de ficar, a necessidade de partir, a ausência deixada e a experiência cultural como bagagem é o que Carlos Dummond de Andrade ressalta nos versos do poema A ilusão do migrante. O poeta sente, nestes versos, muito mais do que pode exprimir. Será com os olhos voltados a este sentimento de "ausência" (SAYAD, 2010), ressaltado pelo poeta, que desenvolveremos as reflexões diante das memórias individuais e coletivas de trabalhadores rurais que, assim como o eu lírico do poema, também migraram na fronteira entre Brasil e Paraguai há, aproximadamente, três décadas e,a partir da primeira década do século XXI,fizeram o movimentode retorno ao Brasil.Será mostrada a trajetória desteshomens e mulheres, trabalhadores ligados às atividades rurais como plantar e colher e que, atualmente, encontram-se vinculados ao Movimento dos Trabalhadores Rurais Sem Terra (MST) na região Oeste do Paraná, município de São 
Miguel do Iguaçu, no Acampamento Sebastião Camargo² ${ }^{2}$, onde em 2018 realizei a pesquisa etnográfica de doutorado.

As memórias migratórias deste grupo de trabalhadores rurais vão tecendo histórias baseadas em sobrevivências, convivências, silêncios e silenciamentos. Ouvir as histórias narradas pelos atuais acampados foi uma das estratégias de aproximação usada na pesquisa de campo, trata-se, portanto, de um Tempo Narrado ${ }^{3}$ envolvendo não só as vozes, mas também os silenciamentos.Contextualizando esse quadro de evento que formula a história da fronteira entre Brasil e Paraguai, é necessário informar que falo de pessoas, famílias, trabalhadores do meio rural, que entre os anos 70 e 80 do século XXI, foram ao Paraguai em busca de sobrevivência. Vários fatores podem ter impulsionado esse fluxo migratório de "ida", portanto é comum encontrar como motivos o alagamento da Usina Hidroelétrica Itaipu Binacional, ou então que foram colocados à margem devido à monocultura e mecanização da agricultura. Entretanto, prefiro entender que esse grupo de trabalhadores, por não serem proprietários de terra antes da alagação da hidroelétrica ou mecanização, foram ao Paraguai em busca de trabalho, de terra para plantar e colher em forma de arrendamento, em síntese, foram atrás de uma forma de sobreviver. Os discursos, principalmente os jornalísticos, que circulam a fronteira trazem esses dois motivos (alagamento/ mecanização) como preponderantes para o fluxo de ida, bem como acrescentam o retorno como resultado da luta entre campesinos paraguaios e agricultores brasileiros. Por ironia, cheguei até os Acampamentos MST depois de seguir as pistas dadas pelos jornais. Entretanto, não encontrei o grupo de pessoas que tinham as experiências de ida pautadas nos motivos relatados nas notícias, nem de retorno conforme descreviam os jornais.

Durante a pesquisa de campo, percebi que havia um apagamento desses grupos de trabalhadores rurais. Eles não apareciam, não tinham existência nos discursos. Além disso o mais complicado estava em entender a ausência do Estado Nacional nas

\footnotetext{
${ }^{2}$ O Acampamento Sebastião Camargo está localizado próximo ao posto de pedágio entre Santa Terezinha de Itaipu e São Miguel do Iguaçu. Cheguei até este acampamento a procura de brasileiros que retornaram do Paraguai, lá encontrei uma comunidade que está ligada ao MST e habita um espaço cedido pelo Assentamento Companheiro Antônio Tavares. Neste acampamento entrevistei nove retornados no segundo semestre de 2018 durante a pesquisa etnográfica que compõe os aspectos metodológicos da pesquisa de doutorado.

${ }^{3}$ Trago o Tempo Narrado em maiúsculas por estar vinculado à tese ainda em conclusão, na qual minha categoria de análise é o Tempo. Nesse sentido, discutona tese, algumas possíveis classificações de tempo encontradas nos acampamentos MST que receberam os trabalhadores rurais retornados. O terceiro capitulo da tese trata do Tempo Narrado e este artigo está baseado nas discussões presentes neste capítulo. 
situações migratórias, muitos retornaram sem documentos dos filhos, ou dos cônjuges. As questões que iam se revelando a cada conversa com os acampados me impulsionavam a saber mais.Parti me esforçando em costurar e reconstruir rotas a partir de narrativas orais. As histórias contadas por eles e ouvidas por mim formaram um significado de temporalidade baseado na lembrança e no esquecimento. Queria saber sobre a experiência migratória deles, como viviam e os motivos de retorno e escrever uma narrativa capaz de contar a história de pessoas ausentes nos discursosque circulam a fronteira. como importante destacar que as narrativas usadas neste texto são as coletadas em 2018, no Acampamento Sebastião Camargo a partir de entrevistas feitas durante a pesquisa etnográfica.

Essas narrativas versam sobre o desejo de conseguir um espaço social, de ser trabalhador no meio rural, de ir e retornar por motivos pluralizados em um contexto total e singulares para aqueles que narram. São narrativas de andanças pelos caminhos que vão além dos limites políticos da fronteira entre o Brasil e o Paraguai, é a exposição do tempo humano, é a experiência temporal que brota histórias singulares, mas parte de um mosaico coletivo. Nesse sentido, este texto lançará mão das reflexões sobre a memória, seja ela individual ou coletiva a partir de Jöel Candau e Maurice Halbwachs; como também dos silenciamentos ocorridos nos discursos a partir de Michael Pollak. Será perceptível que tais narrativas tratam de questões migratórias de ida e retorno, para essa interpretação recorro às ideias de Abelmalek Sayad. Com isso talvez seja possível compreender a presença de trabalhadores ausentes na história, mas presentes no Movimento dos Trabalhadores Sem Terra do Oeste do Paraná.

\section{MEMÓRIAS E ESQUECIMENTOS QUE TECEM AS NARRATIVAS}

Por meio das histórias coletadas dos acampados retornados do Paraguai, encontrei e percorri um caminho tênue entre a memória e o esquecimento. Será neste caminho que pretendo seguir para apresentar um recorte de três décadas da história da fronteira Brasil/Paraguai, envolvendo a migração e o retorno do vivido, da experiência, da sensibilidade e da ação humana, sem, de nenhuma forma, abstrair a presença dos trabalhadores do meio rural que vivem, atualmente, no Acampamento Sebastião Camargo. 
A busca pela memória de trabalhadores que migraram e retornaram é algo preponderante na construção de significados das relações sociais, culturais e de identidade na fronteira entre o Brasil e o Paraguai. Através das aproximações feitas na pesquisa de campo, compreendi que o grupo social que encontrei não se reconhecia como "brasiguaios", entretanto eu os encontrei utilizando o termo como referência, isso influenciada pelas notícias de jornais locais e nacionais que indicavam o paradeiro de brasileiros que retornavam ao Brasil após a disputa pela terra no território paraguaio. Quando iniciei a pesquisa, tive contato com trabalhadores rurais acampados que nunca participaram de disputa por terra no país vizinho, bem como não se reconheciam como "brasiguaios". Percebi que o apagamento desse grupo social estava posto nos discursos que circulam a fronteira, sendo assim recorrer à memória dos retornados seria uma alternativa de grande efeito no contexto da pesquisa e na elaboração de uma história construída a partir da experiência de vida, uma peça existente em um grande mosaico que define aquilo que é dito e não dito nos discursos da fronteira.

Para pensar sobre as narrativas compostas por memórias migratórias e de retorno, decidi seguir as reflexões contidas na obra Memória e Identidade de Jöel Candau, que logo nas primeiras abordagens ressalta que "[...] pela retrospecção o homem aprende a suportar a duração: juntando os pedaços do que foi numa nova imagem que poderá talvez ajudá-lo a encarar sua vida presente” (CANDAU, 2011 p.15). Com isso, Candau mostra a importância da memória como faculdade humana, sendo que sem ela não seria possível criar conexões que estabelecem as lembranças e consequentemente o conhecimento.

Trago as narrativas de acampados a partir da memória individual representando as aprendizagens e experiências de um grupo social. Sendo assim, o processo de lembrar não é visto apenas diante de seu aspecto individual, entretanto é capaz de

\footnotetext{
${ }^{4} \mathrm{O}$ termo "brasiguaio" possui sua história descrita na publicação intitulada Brasiguaios: destino incerto, José Luiz Alves, jornalista, que faz o registro do conflito por terra entre brasileiros e paraguaios na fronteira de Mato Grosso do sul, foi nessa ocasião a primeira vez que se usou a palavra "brasiguaios" pelo Deputado Sérgio Cruz do Partido dos Trabalhadores, referindo-se àqueles que necessitavam de uma anistia para retorno ao Brasil. (ALVEZ, 1990, p.19). É possível também encontrar uma cartografia sobre o termo "brasiguaio" no texto Brasileiros na fronteira com o Paraguai de Márcia Anita Sprandel, a pesquisadora desconstrói a singularidade do termo, reflexão que me foi útil quando encontrei acampados reconhecidos como "brasiguaios" mas que não se reconheciam como tal. Foi possível entender que os "brasiguaios" dos jornais não traziam os trabalhadores que foram ao Paraguai para trabalhar nas terras de outros brasileiros, os que posso considerar os legítimos "brasiguaios" aos quais os jornais se referiam.
} 
organizar uma visão da experiência coletiva. Mas é preciso entender a memória não apenas como um "baú de lembranças", pois há a ressignificação das coisas, a reapresentação da realidade para si e para os outros e finalmente a habilidade de repensar algo. Nesse sentido, entendi que os acampados retornados elaboraram novos significados na experiência de migração, o momento presente que envolve a condição social de trabalhador que não possui a terra é mais significativo que a experiência antiga, o momento político das eleições presidenciais que influenciaria o permanecer ou não no acampamento dominava a forma de pensar dos meus interlocutores. Nas conversas e entrevistas realizadas em 2018, passei por duas condições de trabalho de campo que alteraram bastante o exercício com a memória: as eleições presidenciais e alegação de falta de lembrança da experiência migratória. A vida das pessoas estava com excesso de "agoras". O momento atual estava sempre entrando em diagonal e colocando as memórias antigas em segundo plano, pois a discussão sobre o destino do Movimento dos Trabalhadores Rurais Sem Terra dependia do resultado das eleições. Conseguia compreender a situação instável dos entrevistados no panorama político que influenciava muito as conversas, entretanto, sabia que também necessitaria interpretar o esquecimento da experiência que era recorrente não só nas narrativas orais como nos discursos dos jornais que apresentavam "brasiguaios" generalizando o fluxo migratório e apagando o trabalhador rural que vivia de maneira precária nas fazendas existentes nas colônias.

Buscando respostas às minhas indagações, percorri a obra de Jöel Candau, com o objetivo de saber mais sobre os processos de lembrar individualmente e coletivamente. Candau (2018), a partir do aprofundamento diante da compreensão do conceito de memória coletiva elaborado por Maurice Halbwachs, discute o conceito de memória salientando três níveis: protomemória, memória de evocação e metamemória, diferenciando as memórias fortes e fracas. A protomemória é a memória social presente no corpo, nas ações e no hábito de maneira "[...] imperceptível e sem tomada de consciência [...]" (CANDAU, 2018, p.23). Isso foi possível encontrar na cotidianidade dos acampados em suas tarefas como alimentar os animais (galinhas, porcos) quando eles acionam o passado sem perceber transpondo práticas que já estão incorporadas na experiência. Essas memórias tatuadas também estão presentes na forma de se relacionar com os vizinhos, de preparar os alimentos, organizar o espaço de horta e jardim. A 
memória de evocação é a memória “[...] propriamente dita ou de alto nível, que é essencialmente uma memória de recordação ou reconhecimento [...]" (CANDAU, 2018, p.23), são as aprendizagens que compõem saberes enciclopédicos bem como as sensações e sentimentos. Ela é passível de esquecimento e pode ou não se beneficiar de fatores externos para sua composição e acionamento. Já a metamemória “[...] é a representação que cada indivíduo faz de sua própria memória [...]” (CANDAU, 2918, p. 23) e consequentemente contribui para a formação da identidade. Além disso é uma memória que pode ser passada a nível de grupo e com isso, Candau sinaliza a memória coletiva.

Embora os entrevistados durante a pesquisa etnográfica tenham narrado uma experiência individual, há a participação coletiva que pode ser representada pela família composta pelos pais e irmãos. Além disso, nas histórias, em muitas ocasiões, há a presença de uma pessoa que não possui parentesco, mas vínculo de trabalho com a família, o que impulsiona a ida ao Paraguai para encontrar trabalho no meio rural.

Trago como exemplificação as narrativas de alguns acampados diante da experiência de migrar para o Paraguai. Essa narrativa salienta como causa determinante para o movimento de ida em busca de prosperidade, o que representa um motivo recorrente na fala dos entrevistados, sem levar em consideração as questões agrárias que não eram bem resolvidas no panorama histórico no contexto de luta pela terra no Brasil.

\footnotetext{
Naquela altura do campeonato, meu pai tinha um destino de vender o chão que nós tinha em Santa Quitéria e comprar no Paraguai. Na época, quer ver, em 69, 70, dos anos 70 mais ou menos pelo que me falam, dos anos 70 a 75, ou que seja até 80 . Até porque daí meu pai vendeu. Essa época eu já tinha uns quatro aninho de idade, eu me lembro muito bem, meu pai vendeu a terra. $\mathrm{Na}$ época, se eu não me engano ele vendeu por dois cruzeiros, dois mil cruzeiro e meio. Uma coisa assim! Aí ele queria comprar terra no Paraguai e meu tio pôs na cabeça dele que não. Meu tio falava "não vende, não vende, não vai pra lá, não vai, não vai, porque o Paraguai é assim, o Paraguai vai te tomar a sua família, vai tomar sua terra, e não sei o quê... Porque o Paraguai se você comprou uma posse lá e o cara chega lá e leva a sua mulher embora, leva a sua filha". Então era esse tipo de coisa, meteu um monte de loucura na cabeça do meu pai, meu pai pegou e ficou meio assim, né? Vai, não vai! Bom, o meu pai acabou gastando o dinheiro (Entrevista cedida em 20/11/2018).
}

A narrativa deste acampado sinaliza várias questões significativas dentro do processo migratório, uma delas está no desejo de encontrar um lugar para prosperar, o 
que seria imaginável após a abertura do Paraguai para o recebimento de trabalhadores rurais brasileiros. Há nessa narrativa uma temporalidade marcada, o narrador procura localizar no tempo os acontecimentos para que sua narrativa se aproxime de um fato "verdadeiro", acontecido e citar as datas e os anos torna confiável aquilo que está sendo narrado. Outro ponto significativo está no imaginário que transborda sobre o que encontrariam no Paraguai, a imagem que o tio dele fazia dos paraguaios, o medo de aventurar-se no novo, no desconhecido suprimido por uma postura étnica em relação ao outro que seriam os paraguaios.

Meu interlocutor é um trabalhador de quarenta e nove anos, está no acampamento há aproximadamente dois anos. Passou pela experiência de viver no Paraguai desde criança até a fase adulta. A interpretação desse acampado em relação à experiência no Paraguai não apresentou lado positivo, segundo ele, foi muito difícil sobreviver, ao ponto de perder um filho por desnutrição. Na fala dele fica a presença da dor ao mesmo tempo que a morte do filho foi o ponto mais marcante para a decisão de retornar. Os motivos de ida e retorno são singulares na memória dele. Embora eu perguntasse sobre a infância vivida no Paraguai, ele não conseguia dar detalhes das relações sociais experimentadas, do cotidiano na colônia e nem sobre o que sentia ao morar em outro país. Justificava não lembrar ou que não eram lembranças boas que não valeriam ser ditas. Há então a presença do esquecimento, ou da escolha daquilo que se quer esquecer, o que me remeteu a Michael Pollak, pois em face "[...] dessa lembrança traumatizante, o silêncio parece se impor [...] ao invés de se arriscar a um mal entendido [...]" (POLLAK, 1989, p.3), nesse caso Pollak se referia às lembranças sobre o nazismo. Mas transpondo para a realidade da experiência de pobreza e fome vivida pelos brasileiros no Paraguai, percebi que o silêncio se destacava como um momento de fuga de uma realidade que já passou e sobre a qual eles não queriam lembrar.

Apresento outra narrativa interessante de uma senhora, mãe de três filhos, um deles deficiente. Ela narra um evento muito repetido sobre os acontecimentos que simbolizam o progresso na região aliado à ideia de desenvolvimento a partir da construção da Usina Hidroelétrica de Itaipu. Entretanto a entrevistada elabora outro enredo, é a da experiência de ver o espaço onde morava alagado. Não só o aspecto de perda do "chão", mas também dos direitos de indenização e visibilidade como alguém que habita um lugar. 


\begin{abstract}
Primeira vez que eu fui para o Paraguai foi com 7 anos de idade. A gente morava numa cidade que o lago de Itaipu encobriu, que era Itacoré. Naquela época agente era arrendatário, né, das fazendas. Meus irmãos... Meu pai faleceu eu tinha cinco anos e meus irmãos não tinha assim muito a cabeça para, não teve na verdade uma cabeça para pegar na época uma terra do Incra, porque na verdade a gente devia ser indenizado, né, como a gente era arrendatário os patrão pegaram as terra e a Itaipu indenizou eles e nós fumo descartado! Nois tava livre pra onde nois quisesse ir, NE? Só que a nossa terra que nóis morava os patrão foram indenizado, lógico! Nóis não!!! Os arrendatários num foi! Os arrendatários teve que partir! Pra onde achou melhor e os meus irmãos na época eram jovens também, né? O mais velho acho que tinha 19 anos, que cuidava de nóis com a mãe. Daí eles... Um senhor que também tinha sido indenizado pela Itaipu comprou terra no Paraguai e convidou nóis pra arrendar as terra lá. E por isso que a gente foi pra lá pro Paraguai (Entrevista concedida em 15/10/2018).
\end{abstract}

O Paraguai foi uma alternativa após o alagamento de Itaipu. É interessante observar na narrativa a ideia de liberdade que no início de sua fala é introduzida, uma liberdade que é limitada ao outro que é dono da terra e que convida a família para ir para o Paraguai. Foi a única entrevista que coincidiu com o evento de Itaipu como causador da ida ao Paraguai. Neste acampamento entrevistei um total de nove representantes de famílias que viveram e retornaram do Paraguai, apenas essa senhora sinalizou o alagamento como fator preponderante para a migração. É perceptível na fala dela que a condição básica da família os coloca na condição de arrendatários, não possuíam terras e foram ao Paraguai para trabalhar naquilo que tinham como principal saber. Esse pode ser um fator que tenha influenciado o retorno dessas pessoas, pois o Paraguai também se mecanizou e passou para a monocultura ao longo dos anos e o trabalho para esses agricultores ficou cada dia mais escasso, fator que os colocou, em vários casos narrados, na zona urbana paraguaia. Quando chegaram nas colônias no Paraguai, as famílias cultivavam menta, entretanto, hoje o plantio mecanizado de soja é o grande protagonista nas lavouras paraguaias, o que torna o país vizinho um grande exportador de soja.

Os trechos transcritos embora tenham diferenças entre si, eles apresentam em comum o tema que envolve a ida ao Paraguai e por objetivos muito próximos, como por exemplo a busca de prosperidade e uma vida melhor, ou em último caso a busca pela sobrevivência. Sendo assim a intenção do deslocamento, tema descrito a partir de um resgate de memória, é comum dentre os acampados, constituindo uma ação comum ao 
grupo, além de ser uma experiência da família. Quando um grupo compartilha as memórias entre seus membros, é possível estar falando de memória coletiva.

Nesse contexto de reflexão foi necessário seguir as trilhas da categoria criada por Maurice Halbwachs conhecida por "memória coletiva". Para Halbwachs a recordação e a lembrança não podem ser analisadas de forma efetiva sem levar em consideração os contextos sociais que funcionam como base na reconstrução da memória, sendo assim a memória deixa de ter apenas a dimensão individual, o que fica muito evidente nas narrativas dos acampados. Sempre há outras pessoas envolvidas, o pai, a mãe os irmãos, vizinhos e outros. Há um cenário coletivo, validando que não há memória isolada de um grupo social.

Halbwachs alerta que a memória é um processo de reconstrução, portanto, há de se ter alguns cuidados ao analisá-la. Ela não é uma repetição linear daquilo que aconteceu dentro de um contexto de interesse atualizado, bem como, ela pode se diferenciar quando é evocada e localizada em um tempo e em contexto coletivo. A lembrança é afetiva e sua construção é possível através do convívio social entre indivíduos, portanto a lembrança individual está marcada pela coletividade. Sendo assim, a constituição da memória individual é um resultado da combinação de memórias coletivas dos grupos aos quais o indivíduo está inserido.

Os acampados e retornados do Paraguai participaram de um acontecimento comum no grupo social no qual estão inseridos atualmente: um despejo de uma fazenda no Município de Santa Terezinha do Iguaçu. As "famílias" que em 2016 estavam acampadas em São Miguel, deslocaram-se para a ocupação da fazenda Santa Maria ${ }^{5} \mathrm{em}$ março de 2016 e foram despejados em maio do mesmo ano. Os moradores do Acampamento Sebastião Camargo quando lembram do despejo da fazenda Santa Maria estão construindo uma narrativa que traz a memória coletiva com bastante ênfase e as conclusões sobre a experiência se diferem, pois cada memória individual é um ponto de vista referente à memória coletiva. Transcrevo a narrativa de uma das retornadas do

\footnotetext{
${ }^{5}$ A fazenda Santa Maria, localizada no município de Santa Terezinha do Iguaçu, foi ocupada em março de 2016. Na ocasião pertencia aos irmãos Licínio de Oliveira Machado Filho, presidente da Etesco, e a Sérgio Luiz Cabral de Oliveira Machado, ex-presidente da Transpetro, ambos envolvidos no desvio de dinheiro público na Petrobrás, citados nas delações do doleiro Alberto Youssef e do lobista Fernando Moura, durante as investigações da Operação Lava Jato. Algumas famílias que estavam acampadas no Acampamento Sebastião Camargo ocuparam a fazenda esperando uma negociação do Incra, já que havia irregularidades na propriedade. No dia 18 de maio de 2016 houve o despejo das famílias com a presença de policiais e bastante violência.
} 
Paraguai e que participou do despejo de Santa Maria. Ela lembra-se dos detalhes mais traumáticos na sua experiência de despejo, considerando a presença da violência dos policiais.

\begin{abstract}
Ai ali foi uma experiência horrível, foi uma experiência assim, ele falou assim... Eu tava subindo, né, ele disse pra nóis, pros piá que tava junto "Vocês põe tudo a mochila no chão e põe a mão para trás", eu pensei eles vão metralhar, né? Daí tava meu filho, tava sobrinha do meu ex-marido, tava minha ex-cunhada, nós tava nuns oito, assim. Aí eu não, porque eu estava com meu filho deficiente, né? Meio que entenderam, aí ele falou "A senhora fíca aí". Aí eu falei: "Policial você vai matar o meu filho?" Ele não respondeu. Daí eu falei assim: "Se o senhor via matar, o senhor me avisa porque daí eu quero virar as costas, eu num quero ver. Aí ele não respondeu e eu falei assim "Vai matar eles? Vai fazer que nem fizeram lá com o Camargo?", que é o Sebastião Camargo, né? (Entrevista cedida em $15 / 10 / 2018)$.
\end{abstract}

A lembrança da trabalhadora é bastante individual, ela ressalta seus medos, suas angústias e seu desespero. Mas a narrativa é composta por outras pessoas que ela cita, é uma descrição de um evento coletivo, dessa forma fica evidente que a lembrança dela, embora seja individual, está inserida em um contexto social. Além disso ela estabelece não só uma medida de valor à experiência, sendo "horrível" pela violência sofrida por ela, mas também pelo que ela lembrou de outros conflitos em outros acampamentos quando houve o assassinato de Sebastião Camargo ${ }^{6}$. O acontecimento que ela vivia no momento presente a fez lembrar de outro que ela não havia participado, mas foi construído pela memória coletiva através das narrativas que os grupos vão formulando.

As lembranças podem ser assimiladas de maneiras diferentes por cada membro de um grupo social, trago a narrativa de outra acampada, retornada do Paraguai, no intuito de entender a ordem dada ao mesmo evento, bem como os acontecimentos e o ponto de vista.

Eu fui! Eu fui lá e tem mais essa também! Nós fomos pra Santa Maria, nós saímos daqui e eu acho que era umas três mil famílias, que nós saimo daqui! Tava chegando já, porque nós fomo aqui por dentro, chegaro lá pelos fundos, chegaro em Santa Maria, os caminhão ainda tava aqui dentro, saindo ainda

\footnotetext{
${ }^{6} \mathrm{O}$ assassinato de Sebastião Camargo Filho aconteceu em fevereiro de 1998 e é um símbolo de violência no campo vivido no período do governo Jaime Lerner no Paraná. O trabalhador sem terra foi morto aos 65 anos, quando uma milícia privada ligada a ruralistas despejou ilegalmente famílias acampadas na Fazenda Boa Sorte, na cidade de Marilena, Noroeste do estado, propriedade já considerada improdutiva pelo Incra.
} 


\begin{abstract}
daqui ainda na BR, fechada! Saimo daqui as 2 horas da manhã, as sete horas da manhã tava chegando lá e os caminhão tava saindo daqui ainda. De tanta gente que tinha, Mas no final de conta, depois na hora lá, na luta mesmo, se foi... Foi dum jeito que a gente nunca mais esquece, né? Quando nós cheguemo lá, tudo feliz a gente falou, agora sim tamo num lugar limpo, que vai ser nosso, né? Um lugar muito bonito, bastante terra. Falei, ah! Agora nós podemo plantá... Dentro de dois meses, fora de lá de novo! Cheguemo aqui, fiquemos, nossa! Foi muito sofrimento! E era ainda num dia chuvoso! Chuva, chuva! E o pessoal com as coisa moiando! Tudo na chuva e os policial escoltando o pessoal daqui.

Mas foi violento ou não?

_Não, não foi violento por causa de que nós saimo de lá. Se nós tivesse ficado dentro das casa. Por causa de que quando falou que a policia já tinha entrado por cima na sede, nós tinha saído pra BR. Daí a polícia entrou lá e não encontrou ninguém, mas se eles encontrasse lá nós, seria violento, eles ia bater mesmo! Mas o pessoal já sabia, já! O pessoal que levou nós, porque eles pegaro e sairo tudo, sairo na frente (Severina Quinta de Sebastião Acampamento MST).
\end{abstract}

Essa narrativa de outra trabalhadora rural mostra o ponto de vista sobre a violência dos policiais, diferente do ponto de vista da narrativa anterior. A experiência dessa entrevistada não gerou trauma como a da anterior. O ponto mais interessante é que todos que falaram da ida a Santa Maria exaltam o número grande de famílias, uma grande romaria para a ocupação da fazenda, o que revela que as lembranças serão semelhantes entre os membros do grupo quando um número maior de pessoas tenham vivenciado a experiência e que tenham o mesmo ponto de vista. Embora o evento tenha sido vivenciado coletivamente, a experiência foi individual e assim gerou uma forma singular de se relacionar com o visto e ouvido.

Halbwachs também destaca que para a nossa memória se aproveitar da memória dos outros, não é suficiente a apresentação de testemunhos mas também uma concordância mútua sobre o que aconteceu, essas memórias devem ser concebidas em uma mesma base. Assim, os suportes que assentam a memória individual, dizem respeito às percepções existentes na memória do grupo, assim como pela memória histórica. Será a convivência em um grupo social que construirá a memória não só coletiva, mas a individual também. Acredito que pela idade do acampamento, os moradores ainda estão construindo suas falas e suas histórias, será na convivência com o grupo social que cada um vai tecendo a história coletiva do lugar.

\title{
NARRATIVAS DE RETORNO, QUANDO É IMPOSSÍVEL FICAR
}


O que incide sobre o retorno é a própria essência da migração. Trago as ideias de Abdelmalek Sayad, sociólogo argelino radicado na França, um referencial para pensar os movimentos migratórios (ir e voltar) vividos pelos trabalhadores do meio rural em, aproximadamente, três décadas de experiências. Embora Sayad reflita sobre o movimento migratório de argelinos na França, suas elaborações teóricas trazem debates que podem ser aplicados em outros contextos e assim recorro a essa fonte para entender melhor o movimento de retorno dos trabalhadores acampados.

Ao pensar que "a presença do imigrante é uma presença estrangeira ou que é percebida como tal" (SAYAD, 1998) consigo colocar em evidência os trabalhadores que encontrei no Acampamento Sebastião Camargo, pois alguns deles permaneceram na condição de imigrante e assumiram a identidade de "não nacional" enquanto viviam nas colônias de brasileiros no Paraguai, e isso tinha como significado não possuir direitos e até mesmo representar uma força de trabalho temporária, isso remetendo ao condicionante movimento de ida a partir da abertura da fronteira. Sayad também cita as questões econômicas que envolvem a imigração e que estas podem apresentar, a princípio, o caráter objetivo definido em vantagens e desvantagens e o lucro que o imigrante pudesse corresponder. Diante disso há as intenções do Estado Paraguaio em aceitar os migrantes brasileiros como força de trabalho para impulsionar a produção de grãos.

Quando o imigrante começa a sentir que não há um verdadeiro acolhimento, que ele percebe que está sendo explorado e sem direitos, o sentimento de não pertencer ao lugar é fortificado e os laços com a nacionalidade ficam mais firmes e alinhados como uma espécie de resposta para si, uma forma de não se sentir órfão. Esse sujeito pode ser considerado provisório e durante sua trajetória tenta, pelo veio da memória, aprimorar suas tradições que muitas vezes são traduzidas em solo paraguaio. Esse é o caso da entrevistada que mora no acampamento, ainda criança foi com a mãe e irmãos ao Paraguai, mas retornou ao Brasil após sair da casa da mãe depois de adulta e foi trabalhar na cidade de São Paulo. Casou-se e retornou ao Paraguai fazendo um movimento pendular, depois do nascimento do terceiro filho ela decide retornar ao Brasil por dificuldades na mobilidade no lugar onde ela vivia. Essa experiência de mobilidade na colônia no Paraguai é um tema bastante recorrente nas entrevistas, e trago como exemplo essa narrativa que segue. 


\begin{abstract}
O lugar onde a gente morava era de brasileiro. Só que daí eu tive meu filho especial, né? Aí veio a minha luta, o meu martírio. Porque apesar de ele nascer especial, ele tinha que consultar o neurologista todo mês, tinha que passar os remédio, né? No Paraguai não tinha nada disso, lá. tipo assim, médico de graça, remédio. Então eu... Frauda que eu ganhava tudo aqui da prefeitura. Aí a gente morava num lugar longe de ônibus, enquanto ele era pequeno assim pequeno que agente morava na fazenda, eles trazia eu até numa vila mais próxima eu pegava carona assim com o pessoal que vinha, né? Última vez que eu tinha que vir com ele, porque quando dava o dia de vim no médico tinha que vim. E tinha que tá aqui. E foi essa luta e foi ficando assim por cinco ano. Daí eu fiquei grávida de novo nessa luta com menino e acabei descuidando e fiquei grávida do meu outro menino, aí foi mais difícil ainda minha luta porque às vezes eu fazia vinte quilômetros a pé, um na barriga e outro nas costas. Sabe que eu fui pegando uma... Um desgosto, mas aí quando vim para ter o menino mais novo eu não queria mais voltar (Entrevista concedida em 15/10/2018).
\end{abstract}

A acampada descreve a ausência de assistência à saúde no território paraguaio. A localização da colônia onde morava, embora fosse distante da cidade, possibilitava fazer o movimento pendular de ir e voltar podendo usufruir do atendimento em saúde no Brasil. As condições de sobrevivência no Paraguai é um grande impulso para a iniciativa de retorno para esta trabalhadora, a condição de pobreza a faz novamente se deslocar em busca de algo melhor, voltar seria uma opção. Na sequência da entrevista ela confidencia que sempre quis voltar para o Brasil, pois "viver no Paraguai é muito sacrifício".

A condição do migrante, segundo Sayad, é inerente ao retorno, este por sua vez atribui sentido e explica as relações que podem ser vistas como complexas diante da ideia de ausência e presença. Assim, a ideia de retorno presente naquele que migra é uma forma de manipular uma resposta à sua ausência. Não é implicado nisso apenas voltar a um espaço físico, mas ao espaço social também, o que pode ser considerado uma impossibilidade, pois não se volta àquilo que foi deixado no passado. No caso dos acampados com os quais dialoguei, a vontade de retorno se dava pelo fato de não terem prosperado no Paraguai, não eram donos de fazendas, eram arrendatários e trabalhadores de grandes latifúndios, além disso o acesso à educação e saúde era uma impossibilidade.

O fato de ter a nacionalidade brasileira, para muitos era uma oportunidade de conseguir a inserção nos programas de assistência social no Brasil, o que poderia ser um fator impulsionador para o retorno, mesmo que não fosse para o lugar que deixaram, 
mesmo porque muitos foram para lá ainda crianças e retornaram adultos, o que não gerava grandes vínculos com o lugar deixado. Entretanto, no caso dos adultos que partiram para o Paraguai, há um poder simbólico nessas movimentações que nascem dessa impossibilidade prática de retornar ao que foi deixado no mesmo estado de coisas. Portanto o deslocamento não acontece apenas no espaço físico, mas sobretudo nas relações sociais, refundando novos grupos de sujeitos com novas visões e critérios sociais. Mesmo sabendo disso, muitos que se deslocaram acreditavam que um dia retornariam para o lugar que deixou, dentro da sua originalidade.

Sendo o retorno algo imprevisível, os motivos também são plurais. No caso de uma das acampadas entrevistada o mesmo motivo que a levou para o Paraguai a fez retornar para o Brasil: "conseguir um pedaço de chão"!

\begin{abstract}
A vida foi sofrida! Aí a gente morou só em Cedral, no Paraguai, duas cidade, quer dizer município lá. Moremo em Cedral, Troncal 4, foi de lá que a gente veio daí, aí eu falei assim... Daí foi um pessoal dos Sem Terra lá do Mato Grosso, foro lá e tavam levando pessoas pra, pra morar lá e se acampá. Mas daí a gente não quis, ficou meio com medo, né, fiquemo com medo. Aí foi os daqui, esse pessoal daqui foro lá, aí meu filho falou assim "Mãe vamo lá, vamo lá para nóis, para nóis é ver como que é”. Nóis nunca tinha visto, né? "Vamos lá pra nóis se acampá e para nóis vê como é que é?" Aí eu falei "Então vamos!" E aí, nóis foi. Daí meu filho ficou tempo, meu filho, também a minha nora do outro filho, que mora lá no Troncal. Aí ela ficou tempo também, ela tem uma menina deficiente, ficou tempo também acampada. Eu tive três despejo no acampamento, três despejo feroz! Um foi feroz! (Entrevista cedida em 30/10/2018).
\end{abstract}

A trabalhadora rural e seus filhos decidem retornar para o Brasil para serem integrantes do Movimento dos Trabalhadores Sem Terra. Na fala dela há a presença de receio motivo de colocá-la de fora do movimento, embora tenha passado por várias experiências comuns ao integrante do MST, o despejo por exemplo, que normalmente é com violência e confronto. Mesmo assim, ela se refere aos coordenadores do Acampamento Sebastião Camargo como sendo "eles" e se coloca em outro local social e político, apagando a possibilidade de estar inserida quando não usa o pronome "nós". O sentimento de pertencer ao Movimento MST não faz parte do imaginário desta senhora, mesmo que esteja há muito tempo morando no Acampamento de São Miguel. O caso dela é bastante singular, pois ela fez a ocupação do espaço onde hoje é o Assentamento Companheiro Antônio Tavares, foi despejada e quando os trabalhadores 
conseguiram os lotes, ela ficou na sede do Assentamento, onde hoje está o Acampamento Sebastião Camargo. Prestou serviços para o Assentamento e fícou morando em uma das casas da sede, o que faz com que ela não desenvolva um sentimento de acampada.

O retorno dos brasileiros, hoje acampados, marca uma trajetória entre a cidade e o campo, como lembra uma trabalhadora que está no acampamento desde o início de sua instalação, mas que anteriormente passou pela experiência de viver no meio urbano.

\begin{abstract}
E vim primeiro pro Brasil e aí eu truxe o resto da família tudo atrás de mim, por causa de que eles tava passando muita dificuldade e eu tinha esse piá, eu esperei pra engravidar desse piá com dezessete ano, dezessete ano de casamento pra ter ele, né? Não engravidava, daí quando eu engravidei dele, ele nasceu, ele tinha nove meses eu separei do pai dele. Dai eu falei, vou embora pra lá, né, pro Brasil vê se eu mudo de vida. Aí eu comecei a trabalhar de empregada, daí eu não recebi nada. Trabalhei dezoito anos no Hospital da BR. Depois Curitiba, trabalhei em um restaurante, voltei de novo pra Foz do Iguaçu, aí comecei a trabalhar na Lar, trabalhei na Lar cinco meses e saí de novo por causa que eu caí e me machuquei lá. Fiquei encostada um ano e três meses e daí quando cortou minha, que tava encostada, que resolvi vim pra cá (refere-se ao acampamento) (Entrevista concedida em 27/11/2018).
\end{abstract}

Embora nesse trecho da entrevista ela não dá detalhes das dificuldades, em outra situações a narrativa marca todos os problemas que são comuns: falta de educação, trabalho mal remunerado e falta de assistência médica. No caso dela houve a relação parental como indicativo de retorno de outros membros da família. Ela foi a primeira a se deslocar e depois trouxe a mãe e os irmãos, o retorno toma forma de possibilidade de mudar de vida e aí vai se formando uma rede de retorno parental. Dentre os interlocutores desta pesquisa, a maioria comenta que a família toda retornou, os que permaneceram são os que se estabeleceram através de casamento com paraguaio ou paraguaia e consegue ter uma forma de sobrevivência.

Ao pensar nessas características dos retornados procurei em Carvalho (2006) dados referentes ao fenômeno de retorno de brasileiros que foram ao Paraguai e devido a própria natureza desse fluxo migratório e o meio onde as pessoas vivam, os dados que Carvalho nos traz indicam que os retornados do Paraguai “" [...] continuam, no entanto, a constituir exceção os provenientes do Paraguai, com perfil de escolaridade significativamente pior do que, até mesmo, os chefes de família residentes nas áreas 
não-metropolitanas do Brasil" (CARVALHO, 2006, p. 22). Um indicador de que a educação não era uma realidade no cotidiano desses trabalhadores o que também os limita a disputar trabalhos com melhor remuneração ou que exijam formação escolar. Desta forma submetem-se a empregos na Lar, um símbolo do capital no ramo da indústria na região. Com isso, a condição social dos acampados os mantém em um lugar de improviso, com poucas perspectivas em relação à prosperidade buscada o que os deixa intensamente ligados ao projeto de reforma agrária como uma alternativa de condições sobrevivência com dignidade.

\section{CONSIDERAÇÕES FINAIS}

Neste momento final do texto, mas longe de ser uma conclusão, sinalizo que ainda há muitas perguntas, uma característica fundamental para o texto científico, pois ele não encerra as possibilidades de discussões, mas abre novos questionamentos. Assim, a temática sobre a memória e identidade não se esgota neste texto e ainda pode sofrer mudanças, tendo como ponto de partida a recusa ao homogêneo, sem respeitar as singularidades daqueles que retornaram ao país de origem de forma silenciosa e sem direitos.

Enfim, a condição do migrante ou do retornado é diretamente ligada ao trabalho, na qual sua presença social é sempre relacionada à sua condição humana de trabalhador. A volta torna o brasileiro retornado um imigrante em sua terra de origem, ele sabe que no Brasil ele estará tão pobre quanto no Paraguai, que as condições como trabalhador no meio rural serão tão difíceis quanto em outro país e que possuir um lote para ser produtor rural também é uma estreita e pequena possibilidade. Essas explicações surgem a partir das narrativas orais que traduzem a história de vida de cada um dos acampados que retornaram e se integraram ao Movimento dos Trabalhadores Rurais Sem Terra, bem como pelas conversas informais e observações durante a pesquisa de campo.

Mas essas narrativas orais, que se apresentam como uma saída para refletir sobre o deslocamento desses trabalhadores, dando-lhes visibilidade e voz, também não podem mascarar a realidade que se refere à ausência de dados, a forte ausência do Estado nesse contexto. As narrativas orais jamais superarão a falta de arquivos, dados sociais e 
documentos que permitam desenhar uma política de acolhimento. Diante do apagamento dos brasileiros que migraram para o Paraguai e retornaram ao Brasil, entendi como importante situar as biografias, presentes nas narrativas, nos contextos históricos e sociais dos quais elas nascem, não como indicadores que substituem dados demográficos ou estatísticos, mas como presenças que são ignoradas e que devem ser vistas de alguma forma para construir um significado na história da fronteira.

\section{BIBLIOGRAFIA}

ALVES, J. L. Brasiguaios: destino incerto. São Paulo: Global, 1990.

ANDRADE, C. D. de. Poesia completa e prosa. Rio de Janeiro: José Aguilar, 1973.

CANDAU, J. Memória e identidade. São Paulo: Contexto, 2012.

123-201.

Antropologia da memória. Lisboa, Portugal: Instituto Piaget, 2013. p.

CARVALHO, J. A. M. Migrações internacionais do Brasil nas duas últimas décadas do século XX: algumas facetas de um processo complexo amplamente desconhecido. Coleção Previdência Social. Série estudos; V. 25

HALBWCHS, M. A memória coletiva. Tradução Beatriz Sidou. São Paulo: Centauro, 2003.

SAYAD, A. A imigração ou os paradoxos da alteridade. São Paulo: Edusp. 1998.

SPRANDEL, M. A. Brasileiros na fronteira com o Paraguai. Estudos Avançados, $\mathrm{N}^{\mathrm{o}}$ 20, 2006.

POLLAK, M. Memória e identidade social. Estudos históricos, Rio de Janeiro, vol.05, n.10, 1992. 